\title{
Short-Term Impacts of Prescribed Burning on the Spider Community (Order: Araneae) in a Small Ohio Grassland
}

\author{
SARAH J. ROSE ${ }^{1}$ and P. CHARLES GOEBEL, School of Environment and Natural Resources, Ohio Agricultural Research and \\ Development Center, The Ohio State University, Wooster, OH, USA
}

\begin{abstract}
Prescribed burning is a management tool that is widely accepted for prairie management and restoration, yet little is known how burning may impact the spider community. Although it is generally thought that prescribed burning may alter the spider community composition and structure, few studies have examined these shifts in a controlled manner with both a burned grassland and a nearby unburned companion grassland. On 25 October 2014 we conducted a prescribed burn of a grassland at the Gwynne Conservation Area, London, Ohio. Spiders were sampled using pitfall traps for four weeks pre-burn and six weeks post-burn in both the treatment grassland and adjacent unburned grassland. A total of 298 spiders were collected from sixteen families, over 60 percent of which were in the family Lycosidae. Overall, we found the prescribed burn did not significantly alter the abundance or diversity of spiders collected, and interestingly it appears the community composition of the unburned grassland changed more over the sample period than the burned grassland. Anecdotal observations also suggest that some spiders are capable of surviving the fire in situ. As we continue to study these communities, we will develop a better understanding of the role that prescribed burning plays in regulating the structure and composition of the spider communities. Such information is important to develop process-based restoration and management practices in grassland ecosystems.
\end{abstract}

\section{INTRODUCTION}

Grassland ecosystems provide many valuable services, including but not limited to: soil conservation, water quality enhancement, wildlife habitat, and biodiversity (Risser 1996). Worldwide vast areas of grasslands have been lost to a variety of human land use (Steinauer and Collins 1996). Those grasslands that remain are highly fragmented (Risser 1996) and more susceptible localized extinction events and invasion by non-native species (Risser 1996), thus leading to the conclusion that grassland systems should one of the top priorities of conservation and restoration efforts (Sampson and Knopf 1994).

Before these restoration efforts begin, we need to better understand the natural disturbance regimes and the influence these disturbances have on ecosystem structure and composition, as restoration efforts that emulate natural disturbances and their legacies are more successful (Long 2009). In grasslands, frequent wildfires, usually in the fall and ignited by lightning (Risser 1996, Steinauer and Collins 1996), were important natural disturbances. Fire in grasslands

\footnotetext{
${ }^{1}$ Address correspondence to Sarah J. Rose, 2021 Coffey Rd. The Ohio State University, Columbus, OH 43210. E-mail: rose.891@osu.edu
}

helps reduce the encroachment of woody vegetation (Molles 2008; Hartley 2007), increases nutrient cycling, and creates warm soil conditions that promote seed germination (Kozlowski and Ahlgren 1974). Thus, prescribed burning of grasslands has generally been shown to increase plant productivity (Kozlowski and Ahlgren 1974), and as a result is considered an important and inexpensive restoration and management tool (Whelan 1995; Zelhart and Robertson 2009). Yet, even with the known benefits of burning of grasslands, some are concerned that prescribed burns may negatively impact small isolated populations of invertebrates (Panzer 2002) or reduce beneficial arthropods such as pollinators and predators in these ecosystems (Warren et al. 1987).

Despite their diminutive nature, spiders fill an important role in many ecosystems. As one of the most numerous and higher level predators of the arthropod world (Warren et al. 1987) they have been shown to be good biocontrol agents of many pest and invasive species (Wise 1993) and are important natural enemies of pest insects in many agroecosystems (Buddle et al 2004). Spiders are a diverse group with multifaceted methods of prey capture, each that can serve as an indicator to the habitat in which they reside or utilize. They are also prey for 
many animals, including birds, reptiles, amphibians, fish and mammals (Foelix 2011). Spiders are also abundant in most ecosystems (Wise 1993), and are known to be pioneer colonizers in areas that have been recently altered or disturbed (Bradley and Ohio Biological Survey 2004; Hodkinson et al. 2001). Spiders are also sensitive and respond quickly to environmental conditions (Marc et al. 1999), making them a good choice as bioindicators, especially when considering disturbances and their effects on ecosystem structure and function.

In grassland habitats, it is expected that the number of invertebrates (including spiders) would decrease significantly in the short term following a fire either directly (i.e. mortality) (Reichert and Reeder 1972) or indirectly (i.e. change in habitat structure and microclimate) (Hore and Uniyal 2008; Hartley 2007). Although some have hypothesized that spiders may survive a burn by seeking refuge in the burrows or non-flammable plant matter (Warren et al. 1987; Jansen 2013), Bell et al. (2001) suggested that this was unlikely due to the sensitivity of even the most tolerant spider's physiology to minor changes in temperature. Rice (1932) found that fire temperatures were not severe enough to kill animals that were hibernating in the bases of bunch grass during a spring burn in Illinois, and Brennan et al. (2011) found that Xanthorrhoea preissii (grass trees) can serve as refugia for some invertebrates during fire, although significant mortality was detected. Thus it seems that spiders may be responding to changes in habitat variables altered by burning in addition to direct mortality as a result of the fire.

Taking advantage of a scheduled prescribed burn in a restored grassland in central Ohio planned as a practical experience for students acquiring red card certification as part of a wildland fire management course at The Ohio State University, traps were set up to monitor the spider community in order to determine if there are differences in the spider community following a prescribed burning. Specifically, our primary objective was to quantify the changes in spider species community composition, diversity, and abundance following the prescribed burn, and compare these changes with an adjacent unburned grassland. We hypothesized that a large proportion of the spiders in a grassland treated with prescribed burning will suffer mortality as a result of the prescribed burn, and we would therefore observe a decrease in diversity and abundance in spiders in the time period immediately following a prescribed burn in the burned grassland, but that this decline would not be observed in the adjacent unburned grassland.

\section{Study area}

\section{METHODS}

This study utilized two grassland areas at the Gwynne Conservation area, a 27-hectare (67 acre) demonstration/education area that is part of The Ohio State University's Molly Caren Agricultural Center located in London, Ohio (39.95 N, -83.45 W). The administrators of the wildland firefighter training class (offered through The Ohio State University) selected the Big Bluestem Prairie (BBS -2 hectares) to be used for a prescribed burning training, scheduled to occur on 25 October 2014. This prairie was originally established in 1989 and was planted exclusively as Andropogon gerardii (big bluestem grass), although many other grass and forb species have naturally established in the site since establishment. The Prairie Planting (PP $\sim 0.8$ hectares) was chosen as a companion site for this study. It is approximately 350-m southeast of BBS, was established in 1986 as a mixed-species prairie ecosystem, and was not subjected to any management practices during the spider sampling period.

\section{Spider Sampling}

To characterize the spider community, five pitfall traps were installed along a transect with a minimum distance between traps of 10 meters, and a minimum distance to the grassland edge of 10 meters. At each trap location a hole was dug such that a one gallon flower pot fit snuggly into the hole with the top rim of the pot level with the natural ground. A 0.9-L deli food container with $-5 \mathrm{~cm}$ of propylene glycol/dish soap solution was placed in the flower pot. Propylene glycol was selected as it helps to kill and preserve the specimens in the trap and is less harmful to other wildlife than the alternatives (specifically ethylene glycol). The dish soap acts to reduce surface tension on the solution, causing the caught invertebrates to sink into the solution. The wooden trap, following the design of Bradley and the Ohio Biological Survey (2004) was then placed securely over the catch container and flower pot. The roof and base were constructed using $1 / 4$ " plywood. The base had a $7.6 \mathrm{~cm}$ hole cut into the center in which a solo cup with the bottom removed was inserted to serve 
as a funnel, guiding the invertebrates to the catch container. A $0.6-\mathrm{m} \times 0.6-\mathrm{m}$ piece of chicken wire was secured of the top of the trap with landscape pins to reduce the chance of mammalian disturbance to the traps. Traps were installed on 26 September, 2014, and samples were collected every two weeks thereafter. The traps in both grasslands were removed on 24 October, and the prescribed burn occurred on 25 October. Following the prescribed burn the traps were reinstalled in both areas on 26 October. Samples were collected weekly for the first two weeks post-burn, while subsequent samples were collected every two weeks through 7 December, for a total sample period of four weeks of sampling prior to the burn, and six weeks of sampling following the burn. Spiders and other invertebrates separated and stored in 70 percent ethanol until identification.

Spiders were identified using a Nikon SMZ 1270 stereomicroscope. Identification to genus was completed following Ubick et al. (2005), and identification to species utilized resources available from the World Spider Catalog (2015).

\section{Data Analyses}

Prior to analysis all early instar juveniles (i.e., early stage of development) that were not identifiable past the family level were excluded from all analyses. We also excluded those families that represented less than one percent of the total catch over the entire study period. In addition, Leucauge venusta (family Tetragnathidae) was also excluded, as only one individual was trapped, and unlike the other Tetragnathidaes captured, which are ground-dwelling spiders, $L$. venusta is an orb-web dwelling species.

In order to characterize the differences in the spider community each pitfall trap was treated as an independent replicate and samples were pooled as either pre- or post-treatment and adjusted to per-trapping-week. Pitfall traps can be considered independent if there is sufficient spacing between traps (Woodcock 2005) and several other studies have also treated individual traps as independent (Moore et al. 2002; Moretti et al. 2002; Obrist and Duelli 1996) with a minimum distance of $10-\mathrm{m}$ between traps. Furthermore, in order to provide the most meaningful analysis of these data, even without true replication, the use of inferential statistics can be used in order to provide the most meaningful results (Oksanen 2001).
Shannon Diversity Index (Kent and Cocker 1992) was calculated for each grassland overall, pre- and post-treatment overall, and pre- and post-treatment by grassland. Comparisons between the grasslands and the treatments were analyzed using KruskalWallis tests in R (R Core Team 2013).

Species specific responses were analyzed using an indicator species analysis (Dufréne and Legendre 1997) utilizing the Monte-Carlo procedures (4999 permutations) with PC-ORD software (McCune and Mefford 1999). Indicator species analysis is a statistical approach that uses species fidelity (relative frequency of a species within a group) and exclusivity (relative abundance of a species within a group) to classify species into groups that reflect environmental conditions represented by sample units. In addition, the overall differences in the spider community composition both before and after treatment were determined using Multi-response Permutation Procedures (MRPP). MRPP is a nonparametric procedure that is used to test a-priori groups for differences in composition. (McCune et al 2002). Finally, to further explore the patterns in spider community, both before and after treatment, a nonmetric multidimensional scaling (nMDS) ordination plot was performed with Bray-Curtis distance matrix calculated on per trap week abundances by trap using the vegan package in $\mathrm{R}$ ( $\mathrm{R}$ Core Team 2013). Ordination techniques organize sampling entities along gradients to explain the variability in the data, with nMDS being particularly useful as it reduces the assumption of linearity (McGarigal et al. 2000).

\section{RESULTS}

There were observable changes in the vegetation structure of both grasslands during the study as the prescribed burn consumed most of the vegetation and litter in the BBS, and the PP structure was altered by snowfall and plant senescence (Fig. 1). It should also be noted that the first frost [overnight low temperature of $0^{0} \mathrm{C}\left(32^{0} \mathrm{~F}\right)$ or lower] to occur during the sampling period occurred on 30 October 2014 and additionally there was a snowfall event totaling $7.87 \mathrm{~cm}$ (3.1 in.) on 17 November 2014 . There was a decline in average temperature highs and lows throughout the duration of the study, consistent with the change from fall to early winter.

A total of 298 spiders from 14 families and 29 species were collected. Over 80 percent (244) of 
these spiders were adults or juveniles with enough characteristics to identify to species, genus, or morphospecies, while the remaining nearly 20 percent (54) were only identifiable to family (Supplemental Table 1). Lycosidae (61.7 percent) and Linyphiidae (19.5 percent) were the most abundant families.

Comparisons of the Shannon Diversity Index showed a statistically significant difference between the two grasslands overall $(p=0.02)$. When the data for both grasslands was pooled and the pre- and posttreatment was compared there was no significant difference detected $(p=0.88)$. Additionally, comparing each grassland individually for the pre- and post-treatment there was no significant difference in the Shannon Diversity Index $(p=0.12$ for the both grasslands). Although not statistically significant, it should be noted that there did appear to be an increase in the Shannon diversity index for the BBS when comparing the pre- and the to the post-burn (H' of 1.69 and 1.95 respectively), and the PP showed the opposite trend, with a decrease in the Shannon diversity index between the two sampling periods ( $H^{\prime}$ of 1.71 and 1.49 respectively) (Fig. 2).

MRPP analysis at both the family and species level did not demonstrate any statistically significant differences between the two grasslands $(p=0.08$ for both family and species-level analyses), but comparing the pre-burn to the post-burn overall was significant $(p=0.001)$ (Table 2). Further analysis, comparing the pre- and post-burn of each individual grassland showed a significant difference for both grassland $(p=0.014$ family level BBS, $p=0.013$ species level

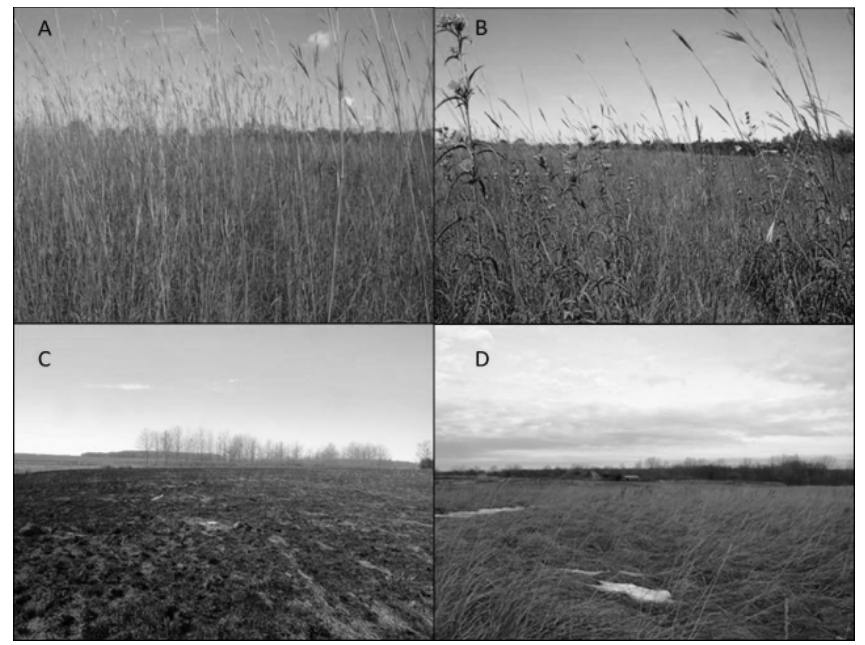

FIGURE 1: (A) Big Bluestem September 2014 (pre-burn); (B) Prairie Planting September 2014; (C) Big Bluestem November 2014 (post-burn); (D) Prairie Planting November 2014.
BBS, $p=0.009$ family level PP, $p=0.005$ species level $\mathrm{PP})$. Indicator species analysis suggests that Varacosa avara (Lycosidae) was associated with the BBS, and Neoantistea agilis (Hahniidae) was associated with the PP. There were three indicators of the Pre-burn and one indicator of the post-burn sampling periods when data from both grasslands were pooled. BBSPre had one indicator species, BBS-post had four indicator species, PP-Pre had two indicator species, and there were no indicators for the PP-Post (Table 3).

The nMDS ordination (Fig. 3) resulted in a two dimension solution with a final stress of 0.153 and shows some overlap of the spider communities of the two grasslands prior to the burn, and shifts after 25 October. The resulting location of the post burn plots demonstrates a greater similarity in the BBS post-burn site to the pre-treatment sites, whereas the PP shows less similarity to either the pre-burn plots or the BBS post-burn.

\section{DISCUSSION}

Most studies have shown a decrease in spider richness and/or abundance in the time postburn when compared to pre-burn and/or control sites (Rice 1932; Dunwiddie 1991; Zelhart and Robertson 2009; Riechert and Reeder 1972; Pascoe 2003). Although it should be noted that these studies [except Riechert and Reeder (1972) that used hand collection and litter sorting] utilized sweep netting sampling exclusively. Sweep-netting is a technique that is most often utilized to sample arthropods dwelling on low vegetation (Ozannne 2005; New

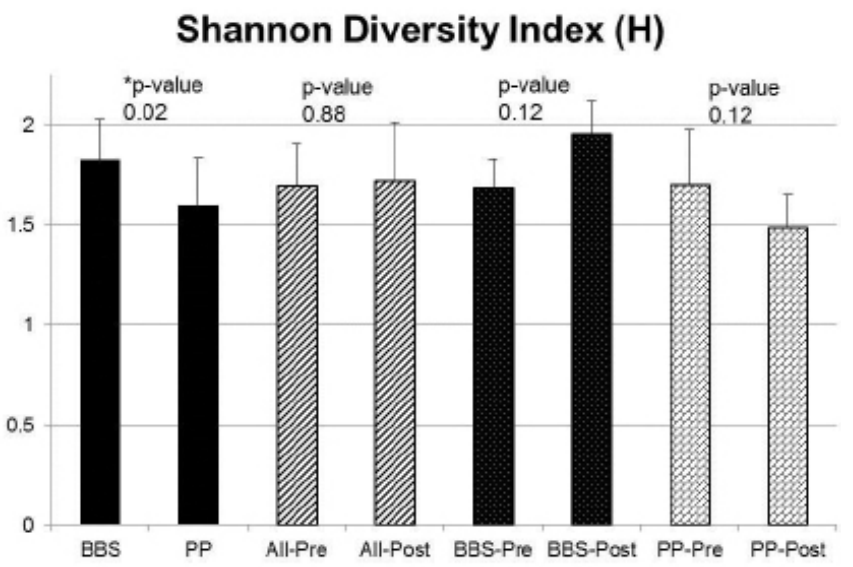

FIGURE 2. Comparison of the Shannon Diversity Index $\mathrm{H}$. Only the comparison of the two grasslands (BBS and PP) was significant ( $p$-value 0.02). Although not significant ( $p$-value 0.12 ) there appears to be an increase in $\mathrm{H}$ when comparing the BBS pre to the BBS post. 
1998). Therefore, in the timeframe immediately following a fire, sweep netting would yield minimal results, as there would be limited vegetation for sweeping to occur on. Ground spiders, on the other hand, have been shown to benefit or have no shortterm impacts from burning in two studies that utilized pitfall trapping (Hore and Uniyal 2008; Jansen et al. 2013). Understanding sampling techniques is an important aspect to arthropod research as there is potential for biases and errors (Leather and Watt 2005). In comparing pitfall traps, sweep nets, and visual searches Churchill and Arthur (1999) found that 94 percent of families were captured in pitfalls, 25 percent with sweep nets and 41 percent by visual sampling. Therefore, when trying to determine short-term effects, when nearly all the vegetation and litter are presumed to be consumed in the prescribed burn, pitfall trapping seems to be the most logical sampling technique to examine the immediate and short term impacts of prescribed burning on spider communities.

We did not find evidence to support the hypothesis that there would be a reduction in diversity and abundance in the time frame immediately following burning. In fact we observed an increasing trend in the Shannon Diversity Index in the burned grassland post burning, although it was not statistically significant. This leads to the conclusion that spiders are either

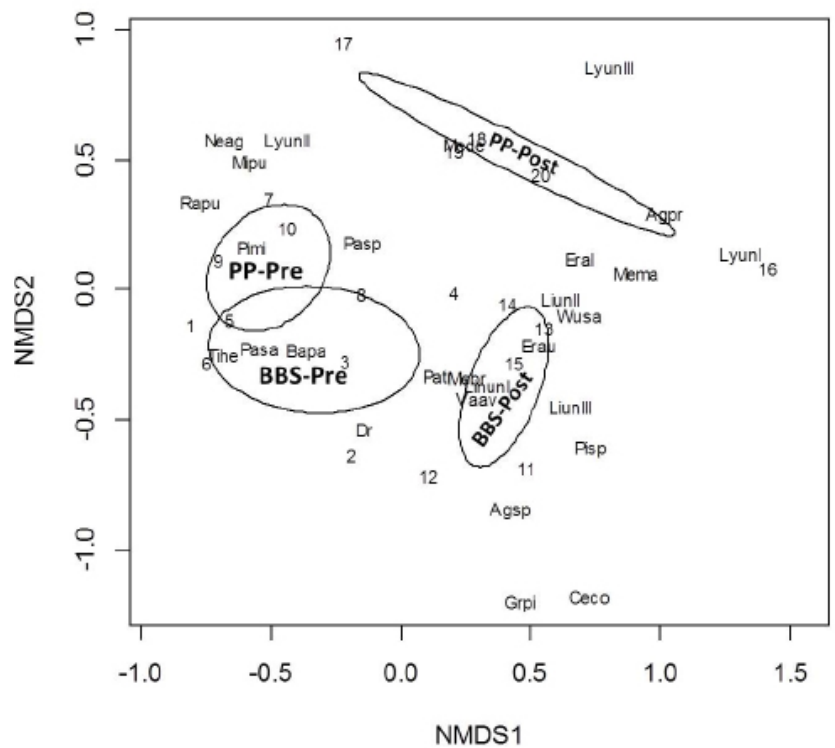

FIGURE 3. nMDS plot of the spider communities, with the ellipses labeled for each site. Stress of 0.1532 .

Table 2

MRPP

\begin{tabular}{|c|c|c|c|c|c|c|c|c|c|}
\hline Comparison & $\begin{array}{l}\text { Species/ } \\
\text { Family }\end{array}$ & $\begin{array}{c}\text { Delta } \\
1\end{array}$ & $\begin{array}{c}\text { Delta } \\
2\end{array}$ & $\begin{array}{c}\text { Delta } \\
3\end{array}$ & $\begin{array}{l}\text { Delta } \\
4\end{array}$ & A & $\begin{array}{l}\text { Observed } \\
\text { Delta }\end{array}$ & $\begin{array}{l}\text { Expected } \\
\text { Delta }\end{array}$ & P-Value \\
\hline $\mathrm{BBS}$ vs PP & Family & 6.675 & 6.646 & na & na & 0.078 & 6.661 & 7.225 & 0.08 \\
\hline BBS vs PP & Species & 6.691 & 6.604 & na & na & 0.075 & 6.648 & 7.12 & 0.08 \\
\hline Pre vs Post & Family & 3.943 & 3.878 & na & na & 0.459 & 3.91 & 7.225 & $<0.01$ \\
\hline Pre vs Post & Species & 4.001 & 3.84 & na & na & 0.455 & 3.921 & 7.19 & $<0.01$ \\
\hline 4 categories & Family & 2.374 & 2.366 & 2.26 & 2.105 & 0.686 & 2.271 & 7.225 & $<0.01$ \\
\hline 4 categories & Species & 2.521 & 2.398 & 2.308 & 2.107 & 0.676 & 2.334 & 7.19 & $<0.01$ \\
\hline BBS Pre vs Post & Family & 2.374 & 2.24 & na & na & 0.654 & 2.307 & 6.675 & 0.01 \\
\hline BBS Pre vs Post & Species & 2.521 & 2.308 & na & na & 0.639 & 2.414 & 6.691 & 0.01 \\
\hline PP Pre vs Post & Family & 2.366 & 2.105 & na & na & 0.664 & 2.236 & 6.646 & 0.01 \\
\hline PP Pre vs Post & Species & 2.398 & 2.107 & na & na & 0.659 & 2.253 & 6.604 & $<0.01$ \\
\hline
\end{tabular}


surviving the fire in situ, or are able to recolonize the area very quickly. In the mop-up phase of the prescribed burn numerous spiders were observed on the burned surface (Fig. 4). In addition, a Varacosa avara (Lycosidae) male was captured in the trapping period of 23 November 2015 to 07 December 2015 with obvious burn injuries to his extremities (Fig. 5). As the burn occurred on the 25 October, one explanation is that he suffered the injuries in the prescribed burn and survived until he was captured

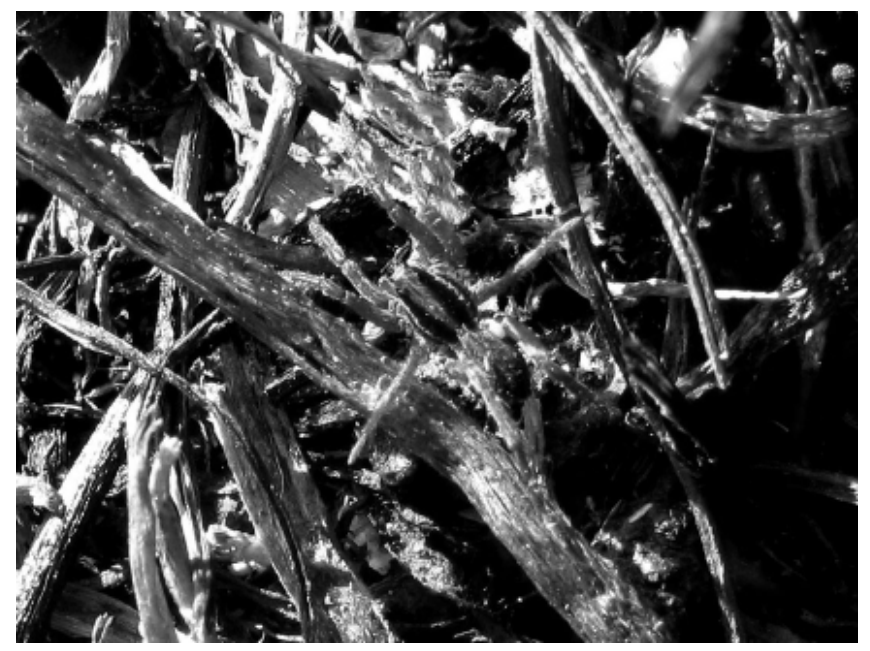

FIGURE 4. Lycosidae seen on the burnt subtracted of the Big Bluestem during the mop-up phase of the prescribed burn. in the pitfall trap several weeks later. Additionally, as there are multiple grassland habitats in close proximity to the burned grassland at the Gwynne Conservation Area, and ballooning spiders were observed on sampling days after the prescribed burn, it is likely that recolonization was also occurring. Other studies have stated the importance of maintaining refuge habitat and varying the spatiotemporal variation (i.e. burning on a rotational basis) among sites in these types of ecosystems (Swengel 2001) in order to provide source populations for recolonization. Thus a combination of survival and recolonization may be responsible for the lack of a decline in diversity and abundance.

Although shifts in community composition were detected, they seem more pronounced for the companion unburned grassland then for the

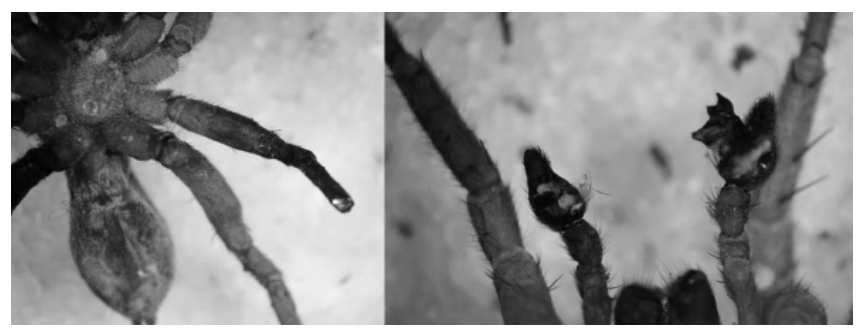

FIGURE 5. Varacosa avara caught in the trapping period 23 November 2014 to 07 December 2014 with visible burn injuries to legs and pedipalps.

Table 3

Indicator Species Analysis by Habitat Type and Sampling Period Species abbreviation (indicator value, $p$-value)

\begin{tabular}{|c|c|c|c|c|c|c|c|}
\hline \multirow[b]{2}{*}{ BBS } & \multirow[b]{2}{*}{ PP } & \multirow[b]{2}{*}{ Pre } & \multicolumn{2}{|c|}{ Habitat Type } & \multirow[b]{2}{*}{ BBS-Post } & \multirow[b]{2}{*}{ PP-Pre } & \multirow[b]{2}{*}{ PP- Post } \\
\hline & & & Post & BBS-Pre & & & \\
\hline Vaav & Neag & Pasa & Agpr & Pasa & Erau & Neag & none \\
\hline \multirow[t]{7}{*}{$(68.2,0.01)$} & $(50.0,0.03)$ & $(70.0,<0.01)$ & $(60.0,0.01)$ & $(83.3,<0.01)$ & $(44.1,0.04)$ & $(48.9,0.05)$ & \\
\hline & & Pimi & & & LinUnkl & Pimi & \\
\hline & & $(70.0,<0.01)$ & & & $(51.8,0.03)$ & $(83.3,<0.01)$ & \\
\hline & & Tihe & & & Vaav & & \\
\hline & & $(81.8,<0.01)$ & & & $(51.5,0.03)$ & & \\
\hline & & & & & Pisp & & \\
\hline & & & & & $(60.0,0.03)$ & & \\
\hline
\end{tabular}


grassland subjected to the prescribed burn. As this study took place in the fall it is possible that these shifts are just part of the phenological changes in spider community that occur naturally each year. As the two grasslands utilized for the study were significantly different in the pre-burn time frame it is not possible to use the unburned as a control, therefore we are not able to conclude if any of the changes were specifically due to the burn. Further studies would need to be completed to evaluate this in more detail, with greater sampling size and better replication. It is clear that we still are lacking in our knowledge of the impact of prescribed burning on the spider community and further studies are warranted in order for land managers and restoration ecologists to gain the insights needed for proper care of these ecosystems.

\section{ACKNOWLEDGMENTS}

Salaries and research support for this research was provided by state and federal funds appropriated to the Ohio Agricultural Research and Development Center (OARDC) at The Ohio State University. We especially thank the support of the Gwynne Conservation Area for allowing us access to the site, especially Nick Zachrich and Marne Titchenell for their assistance in setting up this research project. We also wish to thank The Ohio State University's Wildland Fire Management class (ENR 3335) for executing the prescribed burn, especially Mike Bowden (ODNR) and Dr. Roger Williams (Instructor). We are very grateful to Dr. Richard A. Bradley for his assistance throughout this project, including advising on pitfall trap construction, study design, and tremendous assistance with spider identification. We would also like to thank Timothy Rose for his assistance in the field, and John and Elizabeth Rose for their assistance in constructing the pitfall traps. Finally, we wish to thank the two anonymous reviewers who provided useful editorial suggestions.

\section{LITERATURE CITED}

Bell JR, Wheater CP, Cullen WR. 2001. The implications of grassland and heathland management for the conservation of spider communities: A review. J Zool 255(3): 377-387.

Bradley RA, Ohio Biological Survey. 2004. In Ohio's backyard: spiders. Columbus $(\mathrm{OH})$ : Ohio Biological Survey. 185 p.

Brennan KEC, Moir ML, Wittkuhn RS. 2011. Fire refugia: The mechanism governing animal survivorship within a highly flammable plant. Austral Ecol 36(2): 131-141.
Buddle CM, Higgins S, Rypstra AL. 2004. Ground-dwelling spider assemblages inhabiting riparian forests and hedgerows in an agricultural landscape. Am Midl Nat 151(1): 15-26.

Churchill T, Arthur J. 1999. Measuring spider richness: effects of different sampling methods and spatial and temporal scales. J Insect Conserv 3 (4): 287-295.

Dufrêne M, Legendre P. 1997. Species assemblages and indicator species: the need for a flexible asymmetrical approach. Ecol Monog 67(3): 345-366.

Dunwiddie PW. 1991. Comparisons of aboveground arthropods in burned, mowed and untreated sites in sandplain grasslands on Nantucket Island. Am Midl Nat 125(2): 206-212.

Foelix RF. 2011. Biology of spiders. Toronto (ON). Oxford University Press. 419 p.

Hartley MK, Rogers WE, Siemann E, Grace J. 2007. Responses of prairie arthropod communities to fire and fertilizer: balancing plant and arthropod conservation. Am Midl Nat 157(1): 92-105.

Hodkinson ID, Coulson SJ, Harrison J, Webb NR. 2001. What a wonderful web they weave: Spiders, nutrient capture and early ecosystem development in the high arctic - some counter-intuitive ideas on community assembly. Oikos 95(2): 349-352.

Hore U, Uniyal VP. Effect of prescribed fire on spider assemblage in Terai grasslands, India. Turk J Arachnol 1: $15-36$.

Jansen R, Makaka L, Little IT, Dippenaar-Schoeman A. 2013. Response of ground-dwelling spider assemblages (Arachnida, Araneae) to montane grassland management practices in South Africa. Insect Conserv Diver 6(5): 572589.

Kent M,Coker P. 1992. Vegetation description and analysis: a practical approach. New York. John Willey and Sons. 319 p.

Kozlowski TT, Ahlgren CE. 1974. Fire and ecosystems. New York (NY). Academic Press. 542 p.

Leather SR, Watt AD. 2005. Sampling Theory and Practice. In: Leather SR. Insect Sampling in Forest Ecosystems. Malden (MA) Blackwell Publishing. p. 1-15.

Long, JN. 2009. Emulating natural disturbance regimes as a basis for forest management: a North American view. Forest Ecol Manag 257(9): 1868-1873.

Marc P, Canard A, Ysnel F. 1999. Spiders (Araneae) useful for pest limitation and bioindication. Agr Ecosyst Environ 74(1):229-273.

McCune BJ, Grace JB, Urban DL. 2002. Analysis of ecological communities. Gleneden Beach, OR: MjM Software Design. $300 \mathrm{p}$.

McCune B, Mefford MJ. 1999. PC-Ord: Multivariate Analysis of Ecological Data. MjM Software Design, Gleneden Beach, Oregon.

McGarigal K, Cushman S, Stafford SG. 2000. Multivariate statistics for wildlife and ecology research. New York: Springer. $283 \mathrm{p}$.

Molles MC. 2008. Ecology : concepts and applications. Boston (MA). McGraw-Hill Higher Education. 640 p.

Moore JD, Rock O, Claude C, Houle D. 2002. Effects of two silvicultural practices on soil fauna abundance in a northern hardwood forest, Québec, Canada. Can J Soil Sci 82(1): 105-113. 
Moretti M, Conedera M, Duelli P, Edwards PJ. 2002. The effects of wildfire on ground-active spiders in deciduous forests on the Swiss southern slope of the Alps. J Appl Ecol 39(2): 321-336.

New TR. 1998. Invertebrate surveys for conservation. New York (NY). Oxford University Press. 256 p.

Obrist, MK, Duelli P. 1996. Trapping efficiency of funneland cup-traps for epigeal arthropods. MitteilungenSchweizerische Entomologische Gesellschaft 69: 361-369.

Oksanen, L. 2001. Logic of experiments in ecology: Is pseudoreplication a pseudoissue? Oikos 94(1): 27-38.

Ozanne CMP. 2005. Sampling methods for forest understory vegetation. In: Leather SR. Insect Sampling in Forest Ecosystems. Malden (MA) Blackwell Publishing. p. 58-76.

Panzer R. 2002. Compatibility of prescribed burning with the conservation of insects in small, isolated prairie reserves. Conserv Biol 16(5): 1296-307.

Pascoe F. 2003. Preliminary findings on the impact of prescribed burning on prairie spiders. CW J Best Pract Conserv Restor(1): 17-22.

R Core Team (2013). R: A language and environment for statistical computing. R Foundation for Statistical Computing, Vienna, Austria. ISBN 3-900051-07-0, URL http://www.R-project.org.

Rice LA. 1932. The effect of fire on the prairie animal communities. Ecology 13(4): 392-401.

Riechert SE, Reeder WG. Effects of Fire on Spider Distribution in Southwestern Wisconsin Prairies. In Zimmerman JH. 1972. Proceedings of the Second Midwest Prairie Conference. 1972. Madison (WI) p. 73-90.

Risser PG. A new framework for prairie conservation. In Samson FB, Knopf FL. Prairie conservation : preserving North America's most endangered ecosystem. 1996, Washington, D.C.: Island Press. p. 261-274.
Samson F, Knopf F. 1994. Prairie conservation in North America. Bioscience: 418-421.

Steinauer EM, Collins SL. Prairie ecology - the tallgrass prairie. In Samson FB, Knopf FL. Prairie conservation : preserving North America's most endangered ecosystem. 1996, Washington, D.C.: Island Press. p. 39-52.

Swengel, AB. 2001. A Literature Review of Insect Responses to Fire, Compared to Other Conservation Managements of Open Habitat. Biodivers Conserv 10 (7): 1141-69.

Ubick D, Paquin P, Cushing PE, Roth VD (eds). 2005. Spiders of North America : an identification manual. Poughkeepsie (NY): American Arachnological Society. 377 p.

Warren SD, Scifres CJ, Teel PD. 1987. Response of grassland arthropods to burning: a review. Agr Ecosyst Environ 19(2): 105-30.

Whelan RJ. 1995. The Ecology of Fire. New York (NY): Cambridge University Press. 360 p.

Wise DH. 1993. Spiders in ecological webs. New York (NY): Cambridge University Press. 342 p.

Woodcock BA. Pitfall trapping in ecological studies. In: Leather SR. Insect Sampling in Forest Ecosystems. 2005. Malden (MA) Blackwell Publishing. p. 37-57.

World Spider Catalog. 2015. World Spider Catalog. Natural History Museum Bern, online at http://wsc.nmbe.ch, version 16, accessed on January 27, 2015.

Zelhart MD, Robertson MW. 2009. Annual occurrence and abundance of Araneae families in a tall grass prairie in Illinois before and after a controlled prairie burn. Transactions of the Illinois State Academy of Science 102(3/4): 225-32. 


\section{Supplemental Table 1}

Spiders collected by Grassland and Sampling Period

\begin{tabular}{|c|c|c|c|c|c|}
\hline $\begin{array}{l}\text { Family } \\
\text { genus species (abbreviation) }\end{array}$ & Author & $\begin{array}{l}26 \text { Sept. } \\
\text { 3BS-Pre }\end{array}$ & $\begin{array}{l}-24 \text { Oct. } \\
\text { PP-Pre }\end{array}$ & $\begin{array}{l}26 \text { Oct.- } \\
\text { BBS-Post }\end{array}$ & $\begin{array}{l}7 \text { Dec. } \\
\text { PP-Post }\end{array}$ \\
\hline Anyphaenidae & & $\mathbf{0}$ & $\mathbf{0}$ & 3 & $\mathbf{0}$ \\
\hline Wulfila saltabundus (Wusa) & Hentz 1847 & 0 & 0 & 3 & 0 \\
\hline Araneidae & & 1 & $\mathbf{0}$ & 2 & 2 \\
\hline Araneidae early instars & & 1 & 0 & 2 & 2 \\
\hline Clubionidae & & $\mathbf{0}$ & $\mathbf{0}$ & 1 & $\mathbf{0}$ \\
\hline Elaver sp. (Elsp) & & 0 & 0 & 1 & 0 \\
\hline Dictynidae & & $\mathbf{0}$ & $\mathbf{0}$ & 1 & 1 \\
\hline Circurina robusta (Ciro) & Simon 1886 & 0 & 0 & 1 & 0 \\
\hline Dictynidae unknown I (Diunkl) & & 0 & 0 & 0 & 1 \\
\hline Gnaphosidae & & 3 & 2 & 3 & $\mathbf{0}$ \\
\hline Drassyllus sp. (Drsp) & & 3 & 1 & 3 & 0 \\
\hline Micaria pulicaria (Mipu) & Sundevall 1832 & 0 & 1 & 0 & 0 \\
\hline Hahniidae & & $\mathbf{0}$ & 6 & $\mathbf{0}$ & 2 \\
\hline Neoantistea agilis (Neag) & Keyserling 1887 & 0 & 6 & 0 & 2 \\
\hline Linyphiidae & & 11 & 7 & 35 & 5 \\
\hline Bathyphantes pallidus (Bapa) & Banks 1892 & 6 & 2 & 6 & 1 \\
\hline Centromerus cornupalpis (Ceco) & O. Pickard-Cambridge 1875 & 750 & 0 & 1 & 0 \\
\hline Erigone aletris (Eral) & Crosby \& Bishop 1931 & 0 & 0 & 2 & 1 \\
\hline Erigone autumnalis (Erau) & Emerton 1882 & 0 & 1 & 7 & 1 \\
\hline Grammonota pictilis (Grpi) & O. Pickard-Cambridge 1875 & 750 & 0 & 2 & 0 \\
\hline Mermessus bryantae (Mebr) & Ivie \& Barrows 1935 & 2 & 2 & 3 & 1 \\
\hline Mermessus maculatus (Mema) & Banks 1892 & 1 & 0 & 1 & 1 \\
\hline
\end{tabular}




\section{Supplemental Table 1 (cont.)}

Spiders collected by Grassland and Sampling Period

\begin{tabular}{|c|c|c|c|c|c|}
\hline \multirow{2}{*}{$\begin{array}{l}\text { Family } \\
\text { genus species (abbreviation) } \\
\text { Linyphiidae unknown I (Liunkl) }\end{array}$} & Author & \multicolumn{2}{|c|}{$\begin{array}{l}26 \text { Sept.-24 Oct. } \\
\text { BBS-Pre PP_Pre }\end{array}$} & \multicolumn{2}{|c|}{26 Oct.-7 Dec. } \\
\hline & & 2 & 2 & 11 & 0 \\
\hline Linyphiidae unknown II (Liunkll) & & 0 & 0 & 1 & 0 \\
\hline Linyphiidae unknown III (Liunkl & & 0 & 0 & 1 & 0 \\
\hline Liocranidae & & $\mathbf{0}$ & $\mathbf{0}$ & 6 & 6 \\
\hline Agroeca pratensis (Agpr) & Emerton 1890 & 0 & 0 & 4 & 6 \\
\hline Agroeca sp. (Agsp) & & 0 & 0 & 2 & 0 \\
\hline Lycosidae & & 76 & 55 & 34 & 19 \\
\hline Paradosa saxatilis (Pasa) & Hentz 1844 & 10 & 2 & 0 & 0 \\
\hline Pardosa sp. (Pasp) & & 13 & 12 & 10 & 8 \\
\hline Pirata/Piratula sp. (Pisp) & & 0 & 0 & 3 & 0 \\
\hline Piratula minuta (Pimi) & Emerton 1885 & 2 & 10 & 0 & 0 \\
\hline Rabidosa punctulata (Rapu) & Hentz 1884 & 4 & 5 & 0 & 2 \\
\hline Tigrosa belluo (Tihe) & Walckenaer 1837 & 10 & 10 & 3 & 0 \\
\hline Varacosa avara (Vaav) & Keyserling 1877 & 7 & 1 & 16 & 3 \\
\hline Lycosidae unknown I (Lyunkl) & & 1 & 0 & 0 & 2 \\
\hline Lycosidae unknown II (Lyunkll) & & 0 & 1 & 0 & 1 \\
\hline Lycosidae unknown III (Lyunklll) & & 0 & 0 & 0 & 1 \\
\hline Lycosidae Early Instars & & 29 & 14 & 2 & 2 \\
\hline Mysmenidae & & $\mathbf{0}$ & $\mathbf{0}$ & 1 & $\mathbf{0}$ \\
\hline Mysmenidae unknown (Myun) & & 0 & 0 & 1 & 0 \\
\hline Oxyopidae & & $\mathbf{0}$ & $\mathbf{0}$ & 1 & $\mathbf{0}$ \\
\hline Oxyopes sp. (Oxsp) & & 0 & 0 & 1 & 0 \\
\hline
\end{tabular}




\section{Supplemental Table 1 (cont.)}

Spiders collected by Grassland and Sampling Period

\begin{tabular}{|c|c|c|c|c|c|}
\hline $\begin{array}{l}\text { Family } \\
\text { genus species (abbreviation) }\end{array}$ & Author & $\begin{array}{l}26 \text { Sept.- } \\
\text { BBS-Pre }\end{array}$ & $\begin{array}{l}-24 \text { Oct. } \\
\text { PP-Pre }\end{array}$ & $\begin{array}{l}26 \text { Oct.- } \\
\text { BBS-Post }\end{array}$ & $\begin{array}{l}7 \text { Dec. } \\
\text { PP-Post }\end{array}$ \\
\hline Philodromidae & & $\mathbf{0}$ & $\mathbf{0}$ & 2 & $\mathbf{0}$ \\
\hline Ebo iviei (Ebiv) & Sauer \& Platnick 1972 & 0 & 0 & 1 & 0 \\
\hline Philodromus sp. (Phsp) & & 0 & 0 & 1 & 0 \\
\hline Salticidae & & $\mathbf{0}$ & $\mathbf{0}$ & 2 & $\mathbf{0}$ \\
\hline Marpissa lineata (Mali) & C.L. Koch 1846 & 0 & 0 & 2 & 0 \\
\hline Tetragnathidae & & 3 & $\mathbf{0}$ & 1 & $\mathbf{0}$ \\
\hline Leucauge venusta (Leve) & Walckenaer 1841 & 0 & 0 & 1 & 0 \\
\hline Pachygnatha tristriata (Patr) & C.L. Koch 1845 & 3 & 0 & 0 & 0 \\
\hline Theridiidae & & $\mathbf{0}$ & $\mathbf{0}$ & 2 & $\mathbf{0}$ \\
\hline Theridion sp. (Thsp) & & 0 & 0 & 2 & 0 \\
\hline Trachelidae & & 1 & 1 & $\mathbf{0}$ & 3 \\
\hline Meriola decepta (Mede) & Banks 1895 & 1 & 1 & 0 & 3 \\
\hline
\end{tabular}

